Annals of Warsaw University of Life Sciences - SGGW

Land Reclamation No 42 (1), 2010: 39-49

(Ann. Warsaw Univ. of Life Sci. - SGGW, Land Reclam. 42 (1), 2010)

\title{
Application of a particle swarm optimization to a physically-based erosion model
}

\author{
CELSO AUGUSTO GUIMARÃES SANTOS ${ }^{1}$, LUIZ EDUARDO MAIA PINTO' ${ }^{1}$, \\ PAULA KARENINA DE MACEDO MACHADO FREIRE ${ }^{1}$, SUDHANSHU K. \\ MISHRA $^{2}$ \\ ${ }^{1}$ Department of Civil and Environmental Engineering, Federal University of Paraíba, Brazil \\ ${ }^{2}$ North-Eastern Hill University, Shillong, India
}

\begin{abstract}
Application of a particle swarm optimization to a physically-based erosion model. The difficulties involved in calibration of physically based erosion models have been partly attributable to the lack of robust optimization tools. This paper presents the essential concepts and application to optimize channel and plane parameters in an erosion model, with a global optimization method known as Repulsive Particle Swarm (RPS), a variant of Particle Swarm Optimization (PSO) method. The physically-based erosion model that which was chosen is called WESP (watershed erosion simulation program). The optimization technique was tested with the field data collected in an experimental watershed located in a semi-arid region of Brazil. On the basis of these results, the recommended erosion parameter values for a semi-arid region are given, which could serve as an initial estimate for other similar areas.
\end{abstract}

Key words: particle swarm optimization, runoff erosion simulation, optimization.

\section{INTRODUCTION}

Physically-based distributed models have been largely used to predict runoff and sediment yield in basins, especially those based on kinematic wave assumptions. Although it is a fairly complex task, such models are well suitable for this purpose.
The major problem concerning the use of physically-based model in erosion prediction is the need of parameters which cannot be directly measured in the field. In this context, many algorithms for function optimization are employed to find values for those parameters. However, it is difficult to assure that the final value for the parameter is not a result of either a local minimum or another trap. Therefore, more robust algorithms are required to estimate the parameter's final value. Particle Swarm Optimization (PSO) is a population based stochastic optimization technique, inspired by social behavior of bird flocking or fish schooling. It shares many similarities with evolutionary computation techniques such as Genetic Algorithms (Santos et al. 2003). The system is initialized with a population of random solutions and searches for optima by updating generations. However, unlike GA, PSO has no evolution operators such as crossover and mutation. In PSO, the potential solutions, called particles, fly through the problem space by following the current optimum particles. The detailed information will be given in following sections. Compared to GA, the 
advantages of PSO are that PSO is easy to implement and there are few parameters to adjust. PSO has been successfully applied in many areas: function optimization, artificial neural network training, fuzzy system control, and other areas where GA can be applied. The objective of this work is to use Repulsive Particle Swarm (RPS) method of optimization, which is one of the variants of PSO, for application with the watershed erosion simulation program WESP developed by Lopes and Lane (1988) for a micro-basin in a semiarid region of Brazil. The paper presents the general details of the model and the method.

\section{PARTICLE SWARM METHOD}

The Particle Swarm Optimization (PSO) was invented by Eberhart and Kennedy (1995) inspired by and simulating the behaviour of birds. This method is an instance of a successful application of the philosophy of bounded rationality and decentralized decision-making to solve the global optimization problems (Simon 1982). It is observed that a swarm of birds or insects or a school of fish searches for food, protection, etc. in a very typical manner. If one of the members of the swarm sees a desirable path to go, the rest of the swarm will follow quickly. Every member of the swarm searches for the best in its locality - learns from its own experience. Additionally, each member learns from the others, typically from the best performer among them. Even human beings show a tendency to learn from their own experience, their immediate neighbours and the ideal performers. The Particle Swarm method of optimization mimics the said behaviour. Every individual of the swarm is considered a particle in a multidimensional space that has a position and a velocity. These particles fly through hyperspace and remember the best position that they have seen. Members of a swarm communicate good positions to each other and adjust their own position and velocity based on these good positions. There are two main ways this communication is done: (i) "swarm best" that is known to all (ii) "local bests" are known in neighborhoods of particles. Updating the position and velocity is done at each iteration as follows:

$$
\begin{aligned}
v_{i+1}= & \omega v_{i}+c_{1} r_{1}\left(\hat{x}_{i}-x_{i}\right)+ \\
& +c_{2} r_{2}\left(\hat{x}_{g i}-x_{i}\right) \\
x_{i+1}= & x_{i}+v_{i+1}
\end{aligned}
$$

where $x$ is the position and $v$ is the velocity of the individual particle, the subscripts $i$ and $i+1$ stand for the recent and the next (future) iterations, respectively; $w$ is the inertial constant, good values are usually slightly less than $1 ; c_{1}$ and $c_{2}$ are constants that say how much the particle is directed towards good positions, good values are usually right around 1 . Further, $r_{1}$ and $r_{2}$ are random values in the range $[0,1], \hat{x}_{i}$ is the best that the particle has seen, $\hat{x}_{g}$ is the global best seen by the swarm. This can be replaced by $\hat{x}_{L}$, the local best, if neighborhoods are being used.

The Particle Swarm method has many variants. Proposed by Urfalioglu (2004), the Repulsive Particle Swarm (RPS) method of optimization, one of such variants, is particularly effective in finding out the global optimum in very complex search spaces (although it may be slower on certain types of optimization problems). 
In the traditional RPS the future velocity, $v_{i+1}$ of a particle at position with a recent velocity, $v_{i}$, and the position of the particle are calculated by:

$$
\begin{aligned}
v_{i+1}= & \omega v_{i}+\alpha r_{1}\left(\hat{x}_{i}-x_{i}\right)+ \\
& +\omega \beta r_{2}\left(\hat{x}_{h i}-x_{i}\right)+\omega \gamma r_{3} z
\end{aligned}
$$

where $r_{3} \in[0,1]$ is a random number, $\omega$ is inertia weight, $\in[0.01,0.7], x_{h}$ is best position of a randomly chosen other particle from within the swarm, $z$ is a random velocity vector, $\alpha, \beta$ and $\gamma$ are constants, and the other variables are as defined earlier. Occasionally, when the process is caught in a local optimum, some chaotic perturbation in position as well as velocity of some particle(s) may be needed.

\section{Some modifications in the RPS method}

The traditional RPS gives little scope of local search to the particles. They are guided by their past experience and the communication received from the others in the swarm. We have modified the traditional RPS method by endowing stronger (wider) local search ability to each particle. Each particle flies in its local surrounding and searches for a better solution. The domain of its search is controlled by a new parameter (nstep). This local search has no preference to gradients in any direction and resembles closely to tunnelling. This added exploration capability of the particles brings the RPS method closer to what is observe in real life. However, in some cases moderately wide search (e.g., nstep $=9$ ) works better. It has been said that each particle learns from its 'chosen' inmates in the swarm. Now, at the one extreme is to learn from the best performer in the entire swarm. This is how the particles in the original PS method learn. However, such learning is not natural. It is not expected that the individuals know as to the best performer and interact with all others in the swarm and therefore some rely only on the possibility of a limited interaction and limited knowledge that any individual can possess and acquire. Then, our particles do not know the 'best' in the swarm. Nevertheless, they interact with some chosen inmates that belong to the swarm. Now, the issue is: how does the particle choose its inmates? One of the possibilities is that it chooses the inmates closer (at lesser distance) to it. But, since our particle explores the locality by itself, it is likely that it would not benefit much from the inmates closer to it. Other relevant topologies are (the celebrated) ring topology, ring topology hybridized with random topology, star topology, von Neumann topology, etc.

Let us visualize the possibilities of choosing (a predetermined number of) inmates randomly from among the members of the swarm. This is much closer to reality in the human world. We experience this when we are exposed to the mass media. Alternatively, we may visualize our particles visiting a public place, (e.g. railway platform, church, etc.) where they meet people coming from different places. Here, geographical distance of an individual from the others is not important. Important is how the experiences of others are communicated to us. There are many sources of such information, each one being selective in what one broadcasts and each of us selective in what we attend to and, therefore, receive. This selectiveness at both ends transcends the 
geographical boundaries and each one of us is practically exposed to randomized information. Of course, two individuals may have a few common sources of information.

We have used these arguments in the scheme of dissemination of others' experiences to each individual particle. Presently, we have assumed that each particle chooses a pre-assigned number of inmates (randomly) from among the members of the swarm. However, this number may be randomized to lie between two pre-assigned limits.

\section{THE STUDIED AREA}

The WESP model was utilized to simulate runoff and erosion in a bare micro-basin, which is one of the four micro-basins of the Sumé Experimental Watershed, in the northeastern Brazil. Its mean slope, area and perimeter are $7.1 \%, 0.48 \mathrm{ha}$, and $302 \mathrm{~m}$, respectively.
This experimental watershed was operated from 1982 to 1991 by SUDENE (Superintendency of Northeast Development, Brazil), ORSTOM (French Office of Scientific Research and Technology for Overseas Development) and UFPB (Federal University of Paraíba, Brazil) to obtain field data for calculating the runoff and sediment yield produced by rainfall in a natural environment (Cadier et al. 1983).

The experimental basin includes four micro-basins, nine erosion plots of $100 \mathrm{~m}^{2}$, and several micro-plots of $1 \mathrm{~m}^{2}$ operated under simulated rainfall within a sub-basin of $10.7 \mathrm{~km}^{2}$. The surface conditions and the slope were varied among the plots and micro-basins. Four standard raingauges and two recording raingauges, installed close to the micro-basins and plots, provided the rainfall data. At the outlet of the micro-basins, a rectangular collector was installed for the measurement of water and sediment discharge.

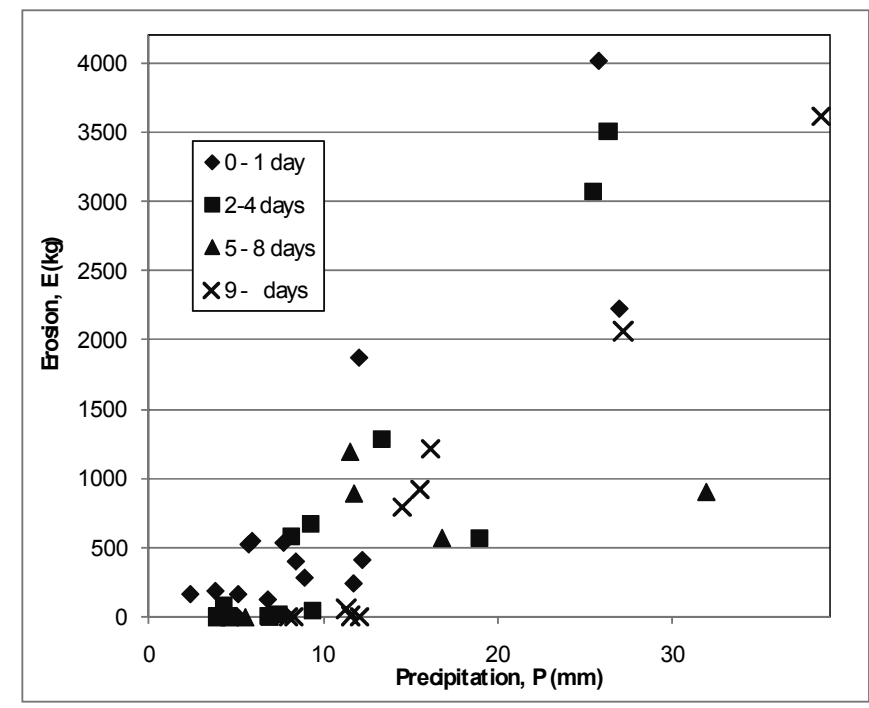

FIGURE 1. Total rainfall depth and sediment yield 
A $90^{\circ}$ triangular weir at the end of the collector allowed the measurement of outflow discharges. The collector held all the surface runoff and sediment discharges for most of the low to medium rainfall events, thereby providing a means for accurate runoff and sediment measurement. Based on the work of Santos et al. (1994), 21 events were selected between 1987 and 1988 and 17 more events were selected between 1989 and 1991 making up a total of 38 events. These periods were chosen because the microbasin was maintained bare during them, under controlled conditions of maintenance. Figure 1 shows the relationship between the total rainfall depth and the corresponding sediment yield, where the observed data are plotted according to antecedent days without rainfall in four groups. The sediment yield is very small when that total rainfall depth is less than about $10 \mathrm{~mm}$ due to the large infiltration capacity of the soil and large evaporation in the semi-arid area. Except for few events, the sediment yield is influenced by the antecedent days without rainfall as well as by the total rainfall depth. Another parameter to characterize the rainfall intensity and duration should be introduced to describe the exceptions.

\section{WESP MODEL}

Lopes and Lane (1988) developed a physically-based distributed model called WESP, which computes runoff and sediment yield based on kinematic waves approximation for the surface flow due to excess rainfall $r_{e}(\mathrm{~m} / \mathrm{s})$, which is obtained by the subtraction of the infiltration rate $f(t)$ from the rainfall intensity $I$, i.e., $r_{e}=$ $=I-f(t)$. The model was developed for small basins to generate the hydrograph and the respective sedigraph. The infiltration process is modelled with the Green-Ampt equation (Green and Ampt 1911), which could be written in the form:

$$
f(t)=K_{s}\left(1+\frac{\Delta \theta \psi}{F(t)}\right)
$$

where, $K_{s}$ is the effective saturated soil hydraulic conductivity $(\mathrm{m} / \mathrm{s}), F(t)$ is the cumulative depth of infiltrated water (m), $\psi$ is the average suction head at the wetting front (m), $\Delta \theta$ is the change in the moisture content, and $t$ is the time variable (s). The moisture content $\theta$ and suction head $\psi$ may be expressed as a single parameter that could be called soil moisture-tension parameter $N_{s}$, such that:

$$
N_{s}=\Delta \theta \psi_{i}=\left(\theta_{s}-\theta_{i}\right) \psi_{i}
$$

where $\theta_{s}$ is the soil moisture content at saturation, which is almost equal to the soil porosity and $\theta_{i}$ is the initial soil moisture content. The surface flow is considered to be either the overland flow on planes or channel flow.

\section{Overland flow}

The spatially varied overland flow is considered one-dimensional and is described by Manning's turbulent flow equation:

$$
u=\frac{1}{n} R_{H}^{2 / 3} \cdot S_{f}^{1 / 2}
$$

where $u$ is the local mean flow velocity $(\mathrm{m} / \mathrm{s}), R_{H}(x, t)$ is the hydraulic radius (m), $S_{f}$ is the friction slope and $n$ is the Manning friction factor. Thus, the local velocity for plane flow could be obtained considering the hydraulic radius equal to 
the depth of flow $\left(R_{H}=h\right)$ and using the kinematic wave approximation resulting in the friction slope being equal to the plane slope $\left(S_{0}=S_{f}\right)$ as:

$$
u=\alpha^{\prime} h^{m-1}
$$

where $h$ is the depth of flow (m), $\alpha^{\prime}$ is a parameter related to surface slope and roughness, equal to $(1 / n) S_{0}^{1 / 2}$, and $m$ is a geometry parameter whose value is set to $5 / 3$ for wide rectangles.

The equation of continuity for the one-dimensional plane could, then, be written as:

$$
\frac{\partial h}{\partial t}+\alpha^{\prime} m h^{m-1} \cdot \frac{\partial h}{\partial x}=r_{e}
$$

From equations (7) and (8), the overland flow velocity and depth $(u, h)$ could be calculated for a given rainfall excess $r_{e}$. The beginning of surface runoff is obtained by determining the pounding time $\left(t_{p}\right)$ for an unsteady rain.

Sediment transport is considered as the erosion rate in the plane reduced by the deposition rate within the reach. The erosion occurs due to raindrop impact as well as surface shear. Thus, the continuity equation for sediment transport is expressed as:

$$
\frac{\partial(c h)}{\partial t}+\frac{\partial(c u h)}{\partial x}=e_{I}+e_{R}-d
$$

where $c$ is the sediment concentration in the surface flow $\left(\mathrm{kg} / \mathrm{m}^{3}\right), e_{I}$ is the rate of sediment erosion due to rainfall impact $\left(\mathrm{kg} \cdot \mathrm{s} / \mathrm{m}^{2}\right), e_{R}$ is the erosion rate due to shear stress $\left(\mathrm{kg} \cdot \mathrm{s} / \mathrm{m}^{2}\right)$, and $d$ is the rate of sediment deposition $\left(\mathrm{kg} \cdot \mathrm{s} / \mathrm{m}^{2}\right)$. The rate of sediment erosion due to rainfall impact $e_{I}$ is a function of the rate of detachment by raindrop impact and the rate of transport of sediment particles by shallow flow. A simple functional form of detachment by raindrop impact could use rainfall intensity as a measure of the erosivity of raindrop impact (Foster 1982), and in order to include the process of sediment transport by shallow flow on hillslopes, Lane and Shirley (1985) included rainfall and expressed $e_{I}$ as:

$$
e_{I}=K_{I} \cdot I r_{e}
$$

where $K_{I}$ is the soil detachability parameter $\left(\mathrm{kg} \cdot \mathrm{s} / \mathrm{m}^{4}\right)$. The rate of sediment erosion due to shear stress $e_{R}$ is expressed by an entrainment rate proportional to a power of the average shear stress acting on the soil surface (Croley 1982; Foster 1982) as:

$$
e_{R}=K_{R} \tau^{1.5}
$$

where $K_{R}$ is a soil erodibility factor for shear $\left(\mathrm{kg} \cdot \mathrm{m} / \mathrm{N}^{1.5} \mathrm{~s}\right)$, and $\tau$ is the effective shear stress $\left(\mathrm{N} / \mathrm{m}^{2}\right)$, which is given by $\tau=\gamma h S_{f}, \gamma$ being the specific weight of water $\left(\mathrm{N} / \mathrm{m}^{3}\right)$. Entrainment and transport of sediment occur when the erosive forces exceed the resisting forces. Water flowing over the soil surface exerts shear forces on the soil particles that tend to move or entrain them. On bare soil surface and stream beds, the forces that resist the erosion by flowing water depend on the size and the distribution of the sediment particles. For coarse sediments, the forces resisting entrainment are mainly frictional forces that depend on the weight of the particles. Finer sediments that contain appreciable fractions of silt or clay, or both, tend to 
be cohesive and resist entrainment due mainly to cohesion than friction. Also, in fine sediments groups of particles (aggregates) get entrained as single units whereas coarse noncohesive sediments are moved as individual particles. Thus, the amount of entrainment is related to the magnitude of total shear stress as expressed in equation (11) rather than to a "critical" shear stress. Finally, the rate of sediment deposition $d$ in equation (9) is not only the deposition of the particular sediment per unit of area and per unit of time, but it also represents the rate at which the column of suspension loses solids per unit of time, and is expressed as (Einstein 1968):

$$
d=\varepsilon_{p} V_{s} c
$$

where $\varepsilon_{p}$ is a coefficient that depends on the sediment and fluid properties, set to 0.5 in the present study based on Davis $(1978), c(x, t)$ is the plane sediment concentration in transport $\left(\mathrm{kg} / \mathrm{m}^{3}\right)$, and $V_{s}$ is the particle fall velocity $(\mathrm{m} / \mathrm{s})$ computed by Rubey's equation:

$$
V_{s}=F_{o} \sqrt{\frac{\left(\gamma_{s}-\gamma\right)}{\gamma} g d_{s}}
$$

and

$$
\begin{gathered}
F_{o}=\sqrt{\frac{2}{3}+\frac{36 v^{2}}{g d_{s}^{3}\left(\frac{\gamma_{s}}{\gamma}-1\right)}}+ \\
-\sqrt{\frac{36 v^{2}}{g d_{s}^{3}\left(\frac{\gamma_{s}}{\gamma}-1\right)}}
\end{gathered}
$$

where $\gamma_{s}$ is the specific weight of sediment $\left(\mathrm{N} / \mathrm{m}^{3}\right), v$ is the kinematic viscosity of water $\left(\mathrm{m}^{2} / \mathrm{s}\right), d_{s}$ is the mean diameter of the sediment (m), and $g$ is the acceleration of gravity $\left(\mathrm{m} / \mathrm{s}^{2}\right)$.

\section{Channel flow}

The concentrated flow in the channels is also described by continuity and momentum equations. The momentum equation could be reduced to the discharge equation with the kinematic wave approximation as:

$$
Q=\alpha^{\prime} A \cdot R_{H}^{m-1}
$$

where $Q$ is the discharge $\left(\mathrm{m}^{3} / \mathrm{s}\right)$, and $A$ is the cross-sectional area of flow $\left(\mathrm{m}^{2}\right)$. The continuity equation for the channel flow is given by:

$$
\frac{\partial A}{\partial t}+\frac{\partial Q}{\partial x}=q_{A}
$$

where $q_{A}$ is the lateral inflow per unit length of channel. Equations (15) and (16) enable the calculation of channel flow. Since the effect of rainfall impact is negligible in the channel, the continuity equation for the sediment is expressed without the rainfall impact component by:

$$
\frac{\partial A C}{\partial t}+\frac{\partial C Q}{\partial x}=q_{s}+e_{r}-d_{c}
$$

where $C(x, t)$ is the sediment concentration in transport in the channel $\left(\mathrm{kg} / \mathrm{m}^{2}\right)$, $q_{s}$ is the lateral sediment inflow into the channel $(\mathrm{kg} \mathrm{s} / \mathrm{m}), d_{c}$ is the rate of sediment deposition in the channel $(\mathrm{kg} \cdot \mathrm{s} / \mathrm{m})$, and $e_{r}$ is the erosion rate of the channel bed material $(\mathrm{kg} \cdot \mathrm{s} / \mathrm{m})$. The components of the net sediment flux for the channel segment are given as follows: the erosion 
rate of the channel bed material $e_{r}$ is obtained from a general equation, initially developed for bed-load transport capacity (Croley 1982; Foster 1982):

$$
e_{r}=a\left(\tau-\tau_{c}\right)^{1.5}
$$

where $a$ is the sediment erodibility parameter, and $\tau_{c}$ is the critical shear stress for sediment entrainment $\left(\mathrm{N} / \mathrm{m}^{2}\right)$, which is given by $\tau_{c}=\delta\left(\gamma_{s}-\gamma\right) d_{s}$, where $\delta$ is a coefficient, set to 0.047 in the present study, $\gamma_{s}$ is the specific weight of sediment $\left(\mathrm{N} / \mathrm{m}^{3}\right)$, and $d_{s}$ is the mean diameter of sediments $(\mathrm{m})$. The rate of sediment deposition within the channel $d_{c}(\mathrm{~kg} \cdot \mathrm{s} / \mathrm{m})$ in equation (17) is expressed by (Mehta 1983):

$$
d_{c}=\varepsilon_{c} T_{W} V_{s} C
$$

where $\varepsilon_{c}$ is the deposition parameter for channels, considered as unity in the present case based on the study of Einstein (1968), and $T_{W}$ is the top width of the channel flow $(\mathrm{m})$. From equation (17), sediment transport rate $(C Q)$ could be calculated for the overland flow with $A$ and $Q$ obtained from equation (16).

\section{APPLICATION AND RESULTS}

\section{Setting of the RPS parameters}

The RPS method contains some probabilistic and deterministic components which are controlled by some algorithmic parameters. For the method to perform optimally, these parameters must be chosen carefully. The following set of parameters was used in the present work: $(N=100, N N=40, M X=100, N S T E P=$ $=15, I T R N=1, N S I G M A=1, I T O P=3)$, in which $N$ is the population size. In most of the cases $N=30$ works well but its value may be increased to 50 or 100 . The parameter $N N$ is the size of randomly chosen neighbours, which ranges from 15 to 25 (but sufficiently less than $N)$ is a good choice. The parameter $M X$ is the maximal size of decision variables. In $f\left(x_{1}, x_{2}, \ldots, x_{m}\right), m$ should be less than or equal to $M X$. The parameter ITRN is the number of iterations. It may depend on the problem. Commonly, the range from 200 (at least) to 500 iterations may be good enough. But for functions like Rosenbrock or Griewank of large size (say $m=30$ ) it is needed that ITRN is large, say 5000 or even 10 000. Exceptionally, the ITRN was set to 1 in order to gain in time execution and the results were satisfactory enough. If ITOP less than or equal to 1 (ring topology); ITOP equal to 2 (ring and random topology); ITOP larger than or equal to 3 (random topology). If NSIGMA is equal to 0 , it means no chaotic perturbation; NSIGMA equal to 1 means chaotic perturbation. In certain cases the one or the other specification works better. Different specifications of parameters may suit different types of functions or dimensions - one has to do some trial and error.

\section{Optimization of the runoff-erosion model}

Firstly, a scheme of planes and channels was selected to represent the studied area. The schematization of the micro-basin in 10 elements was reported (Santos et al. 1994) to be the best scheme to represent the area, thus this schematization was selected in this studied.

In the WESP model some parameter values are fixed a priori such as Manning friction factor, which was assumed 
as 0.02 for planes and 0.03 for channels based on the soil type, its grain size composition and surface characteristics, the specific weight of water $\left(9.8 \mathrm{kN} / \mathrm{m}^{3}\right)$, and the specific weight of sediment $\left(2.6 \times 10^{4}\right.$ $\left.\mathrm{N} / \mathrm{m}^{3}\right)$. However, there are some parameters that are specific for this area which should be determined by field tests such as the saturated soil hydraulic conductivity $K_{s}$ whose average value was set equal to $5.0 \mathrm{~mm} / \mathrm{h}$ and the mean diameter of sediments $d_{s}$ whose value was assumed to be equal to $d_{50}(0.5 \mathrm{~mm})$. The other parameter values should be based either on the literature or determined by calibration with an optimization process.

There are four parameters in the WESP model to be determined by optimization $\left(N_{s}, a, K_{R}\right.$ and $\left.K_{I}\right)$. The first parameter to be calibrated in the WESP model is the soil moisture-tension parameter $N_{s}$ of equation (5), which was calibrated by minimized the following runoff objective function:

$$
J_{L}=\left|L_{o}-L_{c}\right| L_{o}
$$

where $L_{o}$ is the observed runoff depth $(\mathrm{mm})$ and $L_{c}$ is the calculated one $(\mathrm{mm})$.
The remaining three parameters are related to the erosion process, so the optimization had to be done according to the adjustment of computed and observed sediment yield data. Since there are no universally applicable values for these three erosion parameters $\left(a, K_{R}\right.$ and $K_{I}$ ), they were optimized using the RPS method. The range in which these parameters could vary was chosen to be $N_{s}(0.1$ to $200 \mathrm{~mm}), a\left(0.001\right.$ to $\left.0.1 \mathrm{~kg} \cdot \mathrm{m}^{2}\right), K_{R}$ $\left(0.1\right.$ to $\left.10.0 \mathrm{~kg} \mathrm{~m} / \mathrm{N}^{1.5} \mathrm{~s}\right)$, and $K_{I}(0.1 \times$ $\times 10^{8}$ to $\left.10.0 \times 10^{8} \mathrm{~kg} \mathrm{~s} / \mathrm{m}^{4}\right)$.

The initial values of the runoff and erosion parameters were randomly set. The erosion objective function $J_{E}$ to be minimized was:

$$
J_{E}=\left|E_{o}-E_{c}\right| / E_{o}
$$

where $E_{o}$ is the observed sediment yield $(\mathrm{kg})$ and $E_{c}$ is the calculated one $(\mathrm{kg})$. The optimization for the 38 events agreed $100 \%$ with each event. The mean values of the erosion parameters are computed as $a=0.017 \mathrm{~kg} \mathrm{~m}{ }^{2}, K_{R}=2.035 \mathrm{~kg} \mathrm{~m} / \mathrm{N}^{1.5}$, and $K_{I}=4.566 \times 10^{8} \mathrm{~kg} \cdot \mathrm{s} / \mathrm{m}^{4}$ and they were used then to run new simulations. Figure 2 shows the simulation results for

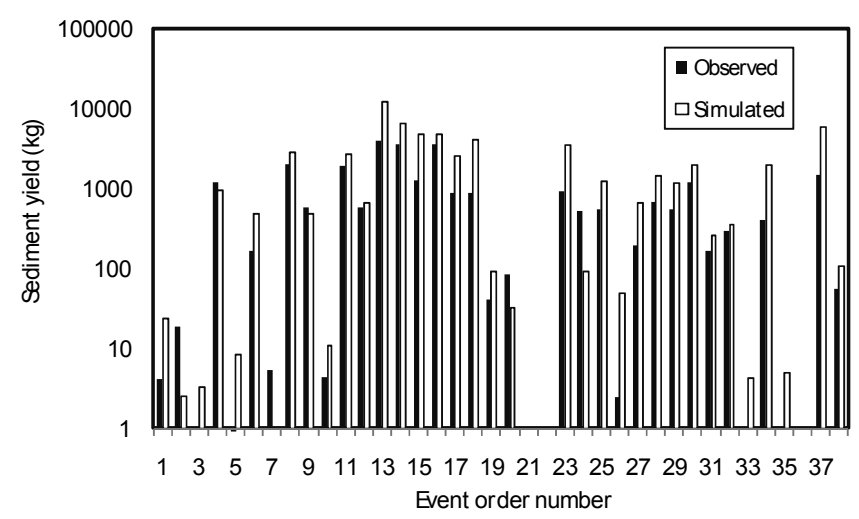

FIGURE 2. Observed and simulated sediment yield 
the sediment yield with some acceptable degree of agreement, except for few events, which can be attributed to some errors in the observed data as well as to the fact that mean parameter values were used for such runs.

\section{CONCLUSION}

A physically-based erosion model was used to simulate the runoff and sediment yield from a micro-basin in a semiarid region of Brazil. The conclusions are as follows: (1) the physically-based erosion model was shown to be useful for simulation in small areas; (2) the RPS algorithm was proved to be a robust optimization technique; (3) the soil moisture-tension parameter $N_{s}$ depends also on the initial moisture content then it should be different for each rainfall event, (4) the channel erosion parameter $a$, the soil detachability factor $K_{R}$, and sediment entrainment parameter by rainfall impact $K_{I}$ are obtained as constant for almost all rainfall events in the experimental basin, i.e. $a=0.017 \mathrm{~kg} \mathrm{~m}^{2}, K_{R}=2.035 \mathrm{~kg} \mathrm{~m} / \mathrm{N}^{1.5}$, and $K_{I}=4.566 \times 10^{8} \mathrm{~kg} \mathrm{~s} / \mathrm{m}^{4}$.

Acknowledgment: The writers wish to thank Dr V. Lopes of Texas State University (US) for providing the WESP source. The field data provided by UFCG (Brazil), SUDENE(Brazil) and ORSTOM (France) are gratefully acknowledged. The financial support provided by $\mathrm{CNPq}$ (Brazil) is gratefully acknowledged.

\section{REFERENCES}

CADIER E., FREITAS B.J., LEPRUN J.C. 1983: Bacia Experimental de Sumé. Instalação e primeiros resultados [Experimental Basin of Sumé. Installation and first results] (in Portu- guese). SUDENE, Recife, Pernambuco, Brazil, p. 87.

CROLEY T.E., II 1982: Unsteady overland sedimentation. J. of Hydrology, Elsevier 56, 325 -346 .

DAVIS S.S. 1978: Deposition of nonuniform sediment by overland flow on concave slopes. MSc Thesis, Purdue University, West Lafayette, IN, USA.

EBERHART R.C., KENNEDY J. 1995: A New Optimizer using Particle Swarm Theory, Proceedings Sixth Symposium on Micro Machine and Human Science, IEEE Service Center, Piscataway, NJ, 39-43.

EINSTEIN H.A. 1968: Deposition of suspended particles in a gravel bed. $J$. of the Hydraulic Division, Proc. ASCE, 94(HY5), 1197-1205.

FOSTER G.R. 1982: Modeling the erosion process. In: Hydrologic modeling of small watersheds (ed. by C.T. Haan, H.P. Johnson and D.L. Brakensiek), Am. Soc. Agr. Eng., 295-380.

GREEN W.H., AMPT G.A. 1911: Studies on soil physics, I. The flow of air and water through soils. J. Agr. Sci., 4(1), 1-24.

LANE L.J., SHIRLEY E.D. 1985: Erosion and sediment yield equations: solutions for overland flow. In Workshop on USLE Replacement, Nat. Soil Erosion Lab., West Lafayette, IN, 22.

LARMAN C. 2007: Utilizando UML e Padrões (Using UML and Pattern, in Portuguese). Ed. Bookman, Porto Alegre, RS, Brazil.

LOPES V.L., LANE L.J. 1988: Modeling sedimentation processes in small watersheds. In Sediment Budgets, ed. by M.P. Bordas and D.E. Walling, IAHS Publication no 174, 497-508.

MEHTA A.J. 1983: Characterization tests for cohesive sediments. In: H.T. Shen (editor), Proc. of the Conference on Frontiers in Hydraul. Engng. ASCE/MIT, Cambridge, Mass., 79-84.

SANTOS C.A.G., SRINIVASAN V.S., SUZUKI, K., WATANABE M. 2003: Application of an optimization technique to a physically based erosion model. Hydrol. Processes 47, 9891003, doi: 10.1002/hyp.1176.

SANTOS C.A.G., SUZUKI K., WATANABE M., SRINIVASAN V.S. 1994: Optimization of coefficients in runoff-erosion modeling by Standardized Powell method, J. of Hydrosci. and Hydraul. Engng, 12(1), 67-78. Japan. Soc. Civ. Engrs.

SIMON H.A. 1982: Models of Bounded Rationality, Cambridge Univ. Press, Cambridge, MA. 
URFALIOGLU O. 2004: Robust Estimation of Camera Rotation, Translation and Focal Length at High Outlier Rates, Proceedings of the 1st Canadian Conference on Computer and Robot Vision, IEEE Computer Society Washington, DC, USA: 464-471.

Streszczenie: Zastosowanie optymalizacji zbioru rozproszonych czasteczek do modelu erozji opartego na podstawach fizycznych. Trudności w kalibracji modeli erozji opartych na podstawach fizycznych przyczyniły się do braku ogólnych narzędzi optymalizacji. W pracy przedstawiono podstawowe koncepcje i zastosowanie do zoptymalizowania parametrów kanału i płaszczyzny w modelu erozji, globalną metodą optymalizacji znaną jako Repulsive Particle Swarm (RPS), wariantem metody Particle Swarm Optimisation (SPO). Fizycznie uzasadniony model erozji, który został wybrany jest nazywany WESP (watershed erosion simulation program). Technika optymalizacji została wypróbowana na danych terenowych zebranych w zlewni eksperymentalnej zlokalizo- wanej w umiarkowanie suchym regionie Brazylii. Na podstawie tych wyników przedstawiono wartości rekomendowanego parametru erozji dla umiarkowanie suchego regionu, który może służyć jako początkowe oszacowanie dla podobnych obszarów.

\section{MS. received April 2010}

Authors' addresses:

\section{Celso A.G. Santos}

Department of Civil and Environmental

Engineering

Federal University of Paraíba

58051-900 Joăo Pessoa, Paraíba

Brazil

e-mail: celso@ct.ufpb.br

\section{S.K. Mishra}

North-Eastern Hill University

Shillong

India

e-mail: mishrasknehu@yahoo.com 